\title{
Beyond the Great and Glorious: Researching Poor Leadership and Bad Governance in Liberal Democracies
}

In contrast to the zealous attention that international political science and related disciplines have paid to studying the performance of great political leaders, the other end of the spectrum - conceptualized and described here as poor leadership and bad governance - has rarely been made the subject of a more ambitious inquiry. This article proposes a conceptual framework for studying poor leadership and bad governance with a special focus on political chief executives, that is, presidents and prime ministers. As an empirical inquiry conducted along these conceptual lines suggests, both phenomena do not necessarily appear together. Ineffective and inefficient leadership by the political chief executive may not always result in bad governance in terms of bad policies. Similarly, poor leaders do not necessarily have to be bad in terms of a lack of respect for the central norms of democratic governance. And indeed, at times precisely the best intentions and a strong moral impetus may even lead to particularly serious weaknesses in terms of effective and efficient leadership.

Im Gegensatz zu der großen Aufmerksamkeit, welche die Politikwissenschaft und die ihr benachbarten Disziplinen dem Studium der Leistungen großer politischer Führungspersönlichkeiten gewidmet haben, ist das andere Ende des Spektrums - das hier mit den Begriffen ,poor leadership" und ,bad governance " bezeichnet wird-bislang selten zum Gegenstand anspruchsvollerer Untersuchungen gemacht worden. Dieser Beitrag präsentiert einen konzeptuellen Rahmen für das Studium schlechter politischer Führung bzw. schlechten Regierens, mit einem speziellen Fokus auf der Rolle von Regierungschefs. Wie eine empirische Bestandsaufnahme entlang dieser konzeptuellen Leitlinien suggeriert, müssen die beiden unterschiedlichen Phänomene nicht zwingend gemeinsam auftreten. Ineffektive und ineffiziente politische Führung durch den Regierungschef schlagen sich nicht zwingend in schlechter Regierungspolitik nieder. Auch müssen ineffektive Regierungschefs nicht zugleich , schlecht“ im Sinne eines mangelnden Respekts vor den zentralen Normen demokratischer Politik sein. Zuweilen scheinen gerade die besten Absichten und ein ausgeprägter moralischer Anspruch guter politischer Führung deren Effektivität und Effizienz im Wege zu stehen. 


\section{I.}

In the greater part of the academic literature as well as in politics itself, the term leadership has a decidedly positive meaning. Indeed, as Barbara Kellerman has pointed out, particularly in the United States leadership is widely considered to be synonymous with good leadership. ${ }^{1}$ There may be a special disposition of the American national character to think of leadership positively which is not fully shared elsewhere, but in few countries, if any, leadership per se carries unequivocally negative connotations. The positive bias in the general understanding of leadership has left its mark on, and been reflected in, empirical leadership research. Scholars have tended to look for positive role-models and "best practice" examples, and have sometimes drawn up ranking lists of leaders holding the same position. The latter is particularly characteristic for the United States where rating and ranking American presidents forms an established part of presidential leadership research. ${ }^{2}$ Among the holders of the modern presidency (established in the 1930s), Franklin D. Roosevelt has widely been considered a rolemodel for all successive presidents. ${ }^{3}$

There is no comparable established tradition of executive leadership research in most other countries, including many of the major Western democracies such as, Germany or France. ${ }^{4}$ But both German and French leadership studies have shared the American inclination to consider one particular incumbent - Konrad Adenauer in Germany, and Charles de Gaulle in France - as a natural yardstick for successive office-holders, and their influence has not been confined to offthe-cuff assessments of later presidencies or chancellorships. In fact, the whole concept of "chancellor democracy", which remains the most influential concep-

I am grateful to John Gaffney (Aston), Ellis S. Krauss (San Diego), Gianfranco Pasquino (Bologna), Gillian Peele (Oxford) and Bert A. Rockman (Purdue) for their valuable comments on different parts of this paper.

1 Kellerman, B.: Bad Leadership: What It Is, How It Happens, Why It Matters, Boston, 2004, 7-10.

2 See, for example, Schlesinger Jr, A.M.: Rating the Presidents: Washington to Clinton, in: Political Science Quarterly, 112/2 (1997), 179-190, and as the latest addition to this growing body of literature, Merry, R.W.: Where They Stand: The American Presidents in the Eyes of Voters and Historians, New York, 2012. Whereas the whole business of presidential rating can be, and has been, challenged in particular for methodological reasons, rating presidents is at least of some use as it forces evaluators (be they political scientists or historians, journalists, or citizens) to think about what they particularly value in political leadership. Vgl. Bose, M./Landis, M. (eds): The Uses and Abuses of Presidential Ratings, New York, 2003.

3 Landy, M./Milkis, S.M.: Presidential Greatness, Lawrence, 2000.

4 The leading American journal Presidential Studies Quarterly alone publishes more substantive articles on executive leadership per year than all major German political science journals together have done in the past quarter century or so. 
tual framework for evaluating the performance of different German chancellors, draws on the rather specific experience of the Adenauer chancellorship. ${ }^{5}$

Not surprisingly, the interest in positive leadership experiences has been even more pronounced among political decision-makers. The search for role-models or, less ambitious, ideas and inspiration can take on international dimensions ${ }^{6}$, but the majority of such efforts has centred on evaluating and emulating previous leaders operating within the respective national environment. Again, there are striking differences between countries. Most American presidents of the post-war period, including Barack Obama, have barely disguised their admiration for Franklin D. Roosevelt. In many parliamentary democracies, there is a more limited willingness of accepting a particular incumbent as a general role-model for future political leaders. For example, despite exceptionally favourable scholarly assessments of the first British post-war Labour prime minister ${ }^{7}$, few supporters and representatives of the Conservative Party would consider Clement Attlee a prime minister to openly turn to for inspiration. It is the differing relevance and meaning of political parties and partisanship under presidential and parliamentary government that are chiefly responsible for this attitude. Party government, which continues to represent the basic political logic in parliamentary systems for all that has been said about its crisis and decline ${ }^{8}$, appears to favour a closer integration of the politics of leadership and the material contents of policy leadership. However, as "leadership" has increasingly come to be regarded as an issue in its own right both by many academic observers and citizens ${ }^{9}$, it has become more common to distinguish between policy substance and leadership performance in a procedural sense. This has more recently inspired the drawing up of rankings of British prime ministers ${ }^{10}$, the conspicuous absence of which has traditionally marked a major difference to the established patterns of execu-

5 Niclauß, K.: Kanzlerdemokratie: Regierungsführung von Konrad Adenauer bis Gerhard Schröder, Paderborn u.a, 2004.

6 On the 'copycat effect in the world of political executives', see Campbell, C.: Political Executives and Their Officials, in: Finifter, A.W. (ed.): Political Science: The State of the Discipline II, Washington DC, 1993, 383-406, here 402.

7 Theakston, K./Gill, M.: The Postwar Premiership League, in: The Political Quarterly, 82/1 (2011), 6780 , here 70 .

8 Mair, P.: The Challenge to Party Government, in: West European Politics, 31/1-2 (2008), 211-243.

9 Foley, M.: The Rise of the British Presidency, Manchester/New York, 1993, 76.

10 See Theakston, K.: Rating 20th Century British Prime Ministers, in: The British Journal of Politics and International Relations, 8/2 (2006), 193-213; Theakston, K./Gill, M.: The Postwar Premiership League, in: The Political Quarterly, 82/1 (2011), 67-80. 
tive leadership research in the United States. And there is an obvious interest of leadership scholars to engage in ranking prime ministers in other countries, too. ${ }^{11}$

This article sets out to look at the other side of the spectrum. It draws attention to those manifestations of leadership by political chief executives, that is presidents and prime ministers that are, by most reasonable standards, not appropriate. Despite several recent attempts to reduce the yawning gap that divides the vast body of research on good and great leaders and leadership, and that on bad leaders and their leadership performances, this subject tends to remain conspicuously understudied. ${ }^{12}$

As in the study of good leaders and good leadership there are numerous perspectives that can be adopted, each of which contributes something specific to the understanding of the greater subject. One of the key aspects of the phenomenon of bad leadership which is in need of considerably more scientific inquiry is the relationship between bad leaders and their followers. Why do followers remain with leaders who are apparently not worthy, and what do such leaders do to retain these followers in supporting them? ${ }^{13}$ Another key aspect, located somewhat beyond the expertise of most political scientists, concerns the psychology of bad leaders. ${ }^{14}$ Yet another question, which is at the centre of this article, relates to what bad leadership means in terms of governance. Any serious attempt at answering this question must begin with breaking down the relationship between leadership and governance - two major subjects that have both received a tremendous amount of attention in recent international research, but which at the same time have largely coexisted in isolation from one another (II.). Hence, it has to be established what can be meaningfully referred to as "poor" and "bad"

11 The volume edited by Michael Strangio, Paul 't Hart and James Walter provides the most ambitious effort as of yet in discussing and rating the performance of prime ministers in different western democracies from a comparative perspective; see Strangio, P./" $t$ Hart, P./Walter, J. (eds): Understanding Prime-Ministerial Performance: Comparative Perspectives, Oxford, 2013 forthcoming.

12 See Kellerman, B.: The End of Leadership, New York, 2012, 194.

13 This aspect is at the centre of Jean Lipman-Blumen's seminal study on 'toxic leadership' and much of the work that has been inspired by this book; see Lipman-Blumen, J.: The Allure of Toxic Leaders: Why We Follow Destructive Bosses and Corrupt Politicians - and How We Can Survive Them?, New York, 2005; see also the special issue of Representation 47/3 (2011), ed. by Timothy Heppell, on "toxic leadership", including Lipman-Blumen, J.: Toxic Leadership - A Rejoinder, in: Representation, 47/3 (2011), 331-342.

14 For a succinct and up-to-date overview of what political psychology as a sub-discipline of political leadership research has to offer, see Renshon, S.A.: The Contributions of Political Psychology to Comparative Leadership Analysis, in: Helms, L. (ed.): Comparative Political Leadership, London, 2012, 186-206. 
in the context of such an inquiry (III.). The fourth section, eventually, provides selected empirical observations from the major liberal democracies (IV.), which also serves the larger goal of reminding ourselves that poor leadership and bad governance are by no means a phenomena that mark only the political practice in non-democratic regimes or structurally defective democracies, but which remain a real possibility in even the most established and advanced democracies.

\section{II.}

There is no established relationship between "leadership" and "governance" in international political research. Conceptual debates tend to centre on "governance" vs. "government" rather than on "governance" vs. "leadership". There is a conspicuous reluctance on both sides to engage in constructive dialogue, with very few exceptions ${ }^{15}$. Many leadership scholars appear to see "governance" as little more than a largely dispensable synonym for what leadership studies have been concerned with from the very beginning. Many scholars associating themselves with the governance paradigm seem to have a more specific problem with "leadership". As a seemingly strictly hierarchical concept, "leadership" contrasts starkly with both the normative and empirical aspects of the governance concept which seeks to overcome hierarchy both theoretically and empirically.

Such perceptions and evaluations are obviously distorted. On the one hand, the governance paradigm certainly is about more than just reintroducing old perspectives under new labels. ${ }^{16}$ On the other hand, many governance scholars clearly have strong reductionist ideas about the conceptual horizon of contemporary leadership studies. The latter have never been confined to studying the actions of office-holders and patterns of formal authority. Even the notions of leadership developed by James MacGregor Burns back in the 1970s define leadership in terms of mobilization rather than coercion and command, and leave much room for ideas of shared leadership and a mutual exchange between leaders and followers. ${ }^{17}$ In particular, the growing appreciation of "soft power"18 in the more

15 Among the most notable attempts to fuse the two concepts of leadership and governance into a larger one is Maarten A. Hajer's recent study on "authoritative governance", Hajer, M.A.: Authoritative Governance: Policy Making in the Age of Mediatization, Oxford, 2011.

16 Rhodes, R.A.W.: What is New about Governance and Why does it Matter?, in: Hayward, J./Menon, A. (eds): Governing Europe, Oxford, 2003, 61-73.

17 Burns, J.M.: Leadership, New York, 1978. 
recent literature makes it no longer tenable to argue meaningfully that leadership research as such has an inherent bias towards institutionalized formal hierarchy and is essentially unable or unwilling to capture other modes or patterns of interaction.

At least two other, more substantive differences between the two concepts would appear to be well worth noting. First, for most scholars, leadership per definition includes followership. It is indeed difficult to imagine leaders without followers, and consequently analysing leader-follower relations is at the very heart of leadership research. ${ }^{19}$ By contrast, the systematic calling into question of established hierarchies in policy-making that characterizes the governance paradigm leaves little room for differentiating between actors that lead and those who follow. That network-based decision-making occasionally takes place "in the shadow of hierarchy", because public actors may threaten to use their formal power of legislation if no consensus emerges, is the utmost that many governance scholars would appear willing to acknowledge. ${ }^{20}$

Second, leadership generally refers more specifically to the actions of individual political actors (including in particular their leadership styles, tactics and strategies), whereas governance tends to focus on the relations and interdependencies between different public and private collective actors. The closest equivalent in governance research to distinguishing leadership styles and strategies in leadership research is the differentiation between "modes of governance", which has more recently come to include attempts at identifying different modes of informal governance. ${ }^{21}$ Also, while leadership and power are not identical, most scholars acknowledge that leadership has something to do with power, and leadership analysis by necessity involves analysing power. ${ }^{22}$ This includes very different aspects - ranging from the power to act upon the different strategies of would-be leaders to secure a reasonably powerful position, or in the case of elected office-holders to stay in office or in power. In contrast, while few gov-

18 In the words of Joseph S. Nye, soft power "co-opts people rather than coerces them" and "rests on the preferences of others to want what you want". See Nye, J.S.: Power and Leadership, in: Nohria, N./Khurana, A (eds): Handbook of Leadership Theory and Practice, Boston, 2010, 305-332, here 307.

19 Kellerman, B.: Followership: How Followers are Creating Change and Changing Leaders, Boston, 2008; Keohane, N.O.: Thinking about Leadership, Princeton, 2010, 48-82.

20 Heritiè, S./Lehmkuhl, D.: The Shadow of Hierarchy and New Modes of Governance, in: Journal of Public Policy, 28/1 (2007), 1-17.

21 Peters, B.G.: Forms of Informality: Identifying informal governance in the European Union, in: Perspectives on European Politics and Society, 7/1 (2006), 25-40.

22 Nye, J.S.: Power and Leadership, op.cit. 
ernance scholars would deny that different manifestations of governance cannot be understood without analysing the underlying patterns of power, the key dependent variable in most of the governance literature is clearly problem-solving rather than power as such.

Notwithstanding these differences, there is some shared ground between conceptions of "good leadership" and "good governance". Most leadership scholars consider both "effectiveness" and "ethics" key components of good leadership. Effectiveness is central to most governance concepts too, even if customarily more narrowly conceptualized as effective problem-solving. Most conceptualizations of "good governance" also include at least some normative elements conditioning the quest for effectiveness. More specifically, many popular notions and concepts of "good governance" centre strongly on the creation and/or the existence of certain institutional arrangements that facilitate democratic accountability and help ward off corruption and economic mismanagement. Some authors, such as Mark Bevir, consider strong leadership (by the state) necessary for bringing about institutional reforms that result in such institutional structures. ${ }^{23}$ Many established leadership studies tended to take the institutional context in which leaders operate as more or less fixed and given, defining the task of leaders as "making the best of it". More recent contributions to the debate concerning "good leadership", however, emphasize that "one of the most important skills of good leaders is to design and maintain systems and institutions" 24 - including those that allow an orderly recruitment of immediate successors and future leaders. Indeed, acknowledging the close interdependence between actors and institutions has become a conceptual cornerstone of contemporary political leadership research.

\section{III.}

But what then, is "poor leadership" and "bad governance"? Recent political research has invested considerably more time and energy in exploring "bad leadership" than in reflecting upon "bad governance". The latter is often, even in more ambitious contributions, narrowly defined in terms of bad economic policy. $^{25}$ Such conceptual minimalism in much of the literature dealing with "bad

23 Bevir, M.: Democratic Governance, Princeton, 2010, 97-98, 181-182.

24 Nye, J.S.: The Powers to Lead, Oxford, 2008, 128.

25 Osborne, E.: Measuring Bad Governance, in: Cato Journal, $23 / 3$ (2004), 403-422. 
governance" contrasts starkly with the richness of the recent debate on "bad leadership". 26

The key differentiation between various forms of "bad leadership", according to Kellerman, relates to "ineffective leadership" on the one hand and "unethical leadership" on the other ${ }^{27}$. The same author has distinguished between seven different forms of bad leadership, the first three of which centre on ineffectiveness: The lightest and arguably most common form of ineffectiveness, according to Kellerman, is incompetence, "a lack [of] will or skill (or both) to sustain effective action" ${ }^{28}$ Rigidity marks a second form or source of ineffectiveness. Leaders in this category tend to be "stiff and unyielding. Although they may be competent, they are unable or unwilling to adapt to new ideas, new information, or changing times". ${ }^{29}$ Finally, there are intemperate leaders. A leader of this kind typically "lacks self-control and is aided and abetted by followers who are unwilling or unable effectively to intervene". 30

The majority of Kellerman's seven types of bad leadership are bad in terms of unethical leadership, though: Leaders may be callous ("uncaring and unkind") and/or corrupt (the leader "lies, cheats or steels" and "puts self-interest ahead of the public interest") as well as insular (meaning that he or she "minimizes or disregards the health and welfare of "the other'", which tends to be of particular relevance in foreign policy) or, finally and most abhorrent of all, evil (willing "to use pain as an instrument of power"). ${ }^{31}$

Many elements identified and discussed by Barbara Kellerman can also be found in Jean Lipman-Blumen's study on "toxic leadership". ${ }^{32}$ Toxic leaders engage in numerous "destructive behaviours" and exhibit certain "dysfunctional personal characteristics". 33 The latter are rather unspecific and may give rise, or contribute, to "incompetent leadership" (for example through "failure both to

26 "Bad power", part of the title of a sweeping account of the evolution of government, somehow seems to fall in between the two and involves aspects of both "poor leadership" and "bad governance", as conceptualized below Mulgan, G.: Good and Bad Power: The Ideals and Betrayals of Government, London, 2006.

27 Kellerman, B.: Bad Leadership, op. cit., 32-37.

28 Ibid., 40.

29 Ibid., 41.

30 Ibid., 42.

31 Ibid., 43-46.

32 Lipman-Blumen, J.: The Allure of Toxic Leaders, op. cit.

33 Ibid., 18. 
understand the nature of relevant problems and to act competently", or simply "cowardice") as well as to "unethical leadership" (for example through "insatiable ambition" or "amorality that makes it nigh impossible [...] to discern right from wrong") 34 .

The "destructive behaviours" singled out by Lipman-Blumen include some features that could be classified as aspects of "ineffective leadership", such as "ignoring or promoting incompetence" or "stifling constructive criticism". ${ }^{35}$ Yet, the great majority of problematic activities distinguished are better described, in Kellerman's categories, as manifestations or elements of "unethical leadership". This is true for leaders' willingness to mislead followers through deliberate untruths and misdiagnoses of issues and problems as much as for actions that Lipman-Blumen describes as "maliciously setting constituents against one another". 36

As with Kellerman's worst forms of unethical leadership, some "destructive behaviours" identified by Lipman-Blumen are clearly incompatible with any form of democratic leadership, or leadership in democratic contexts. Leaders who deliberately "violate the basic standards of human rights" or engage in "building totalitarian or narrowly dynastic regimes" 37 are no democratic leaders nor should they be entrusted with leadership offices and functions in democratic regimes.

For the purposes of this article, the term poor leadership is primarily used as a synonym for ineffective leadership - leadership that fails to achieve its self-set goals chiefly because of the incompetence, the ignorance, the rigidity or the intemperateness of the leader. At times leadership ineffectiveness in politics can also result from high moral standards that may give rise to moral qualms which, eventually, may effectively undermine a leader's capacity to act politically. A sub-type of poor leadership is inefficient leadership. Inefficient leaders may achieve their goals, if typically only some of them, but at a high or possibly too high a price. Poor leadership in terms of ineffective leadership incurs unreasonably high costs. Such costs may involve a wealth of different resources, such as time, money or personnel. Arguably the most genuinely political costs in democratic regimes are "electoral costs", which are the losses in electoral support that 
governing parties usually have to pay for their participation in government. ${ }^{38}$ Another sub-type of poor leadership is marked by the absence of a more concrete leadership agenda - leadership that lacks substantive and clearly defined goals. This third type of poor leadership characterizes leaders of administrations that simply do not know what exactly to do with their power. Other things being equal, this seems to be a problem among politically conservative administrations that are keen to defend the political and social status quo, but which may possibly fail to realize the deeper meaning of Giuseppe di Lampedusa's famous dictum about stability and change.

Bad governance, the second key term of this inquiry, also has various meanings: First, it is understood here, in terms of bad policies (ill-conceived and/or poorly implemented) and bad outcomes of government policies for society. Such policyrelated notions arguably represent the most familiar understanding of bad governance, although usually too narrowly confined to manifestations of bad economic policy. Second, and no less importantly, bad governance refers to violations of central norms of liberal democracy or democratic governance, such as transparency, procedural fairness or accountability. Unlike some notions of "bad leadership" that centre on leaders' personalities, the focus of this second dimension of bad governance is on the deficient democratic quality of decision-making and its systemic consequences. Obviously, not all manifestations of this second form of bad governance are as equally bad. There are not only differences concerning the degree to which the basic norms of liberal democracy and democratic governance are violated, balanced assessments of bad governance also have to establish how much good (at the level of goals and consequences) comes out of decision-making practices that may lack certain elements of good governance. ${ }^{39}$

Even such careful conceptual demarcations as established above cannot provide perfect clarity if being used for comparative empirical inquiries. Context matters

38 In fact, in the majority of cases governments (that is, governing parties) tend to lose electoral support from election to election, though the concrete electoral performance of parties is dependent on the structure of the party system and in particular the performance of governments. For figures and assessments from Western Europe, see Müller, W.C./Strøm, K.: Conclusion, in: Müller, W.C./Strøm, K. (eds): Coalition Governments in Western Europe, Oxford, 2000, 559-592, here 589 and Giger, N.: Do Voters Punish the Government for Welfare State Retrenchment? A Comparative Study of Electoral Costs Associated with Social Policy, in: Comparative European Politics, 8/4 (2010), 415-443.

39 Recent democratic theory acknowledges that good decisions may to some extent compensate for democratic deficits in public policy making, but there is a broad consensus that output legitimacy can and should complement, rather than replace, input legitimacy; see Scharpf, F.W.: Problem-Solving Effectiveness and Democratic Accountability in the EU, MPIfG Working Paper 03/1, February 2003. 
both for the pursuit as well as the public perception of leadership, and contextual aspects include not just the basic institutional and political parameters but also the political culture of a given polity. "A virtuous character in some cultures would not seem so in another". ${ }^{40}$ What may be seen as resolute leadership in some countries may be considered as overly harsh and rigid in others. Just as leadership personalities, leadership styles have to be looked at in context. ${ }^{41}$ If there is an obvious mismatch between a particular leadership style and the cultural parameters of a given polity, this is also likely to affect the effectiveness of the former, especially when the basic institutional arrangements embody the cultural values of society (as is usually the case in democratic systems). A prime minister committed to a policy of "no U-turns" and little compromise is unlikely to achieve much in a consensus democracy, whereas a committed consensusseeker in majoritarian democracies might easily become (or at least come to be considered) an "underachiever".

In particular, the exact frontiers between good and bad leadership and governance - whenever considered in democratic contexts - remain contested. The complex relationship between political leadership and democratic responsiveness is a case in point. While good democratic leadership is widely considered to include a reasonable amount of responsiveness of leaders to the demands of their supporters (as well as other citizens), responsiveness may have far-reaching and mostly problematic consequences. As Jeffrey Cohen, writing on the US presidency, has argued, "the cost of short-term presidential responsiveness to public opinion is that presidents must cede some control over the substance of public policy to the public. This may mean that the policies that result may be less effective than they could have been had the president controlled their construction. (...) And less effective policies limit the ability of presidents to build their reputation, which limits the ability to build longer-term public support". ${ }^{42}$ While this phenomenon has rarely been studied empirically outside the US, the thrust of the argument would appear to apply to leaders in any democratic system.

Another prominent source of disagreement when it comes to distinguishing between good and bad leadership is the increasing relevance of "soft power". There is a growing understanding that effective leadership today almost always draws

40 Nye, J.S.: The Powers to Lead, op.cit, 119.

41 Bell, D.S./Hargrove, E./Theakston, K.: Skill in Context: A Comparison of Politicians, in: Presidential Studies Quarterly, 29/3 (1999), 528-548.

42 Cohen, J.E.: Presidential Responsiveness and Public Policy-Making, Ann Arbor, 1997, 15. 
to a significant extent on "soft power". Generally, "soft power" is widely considered to be strongly preferable to "hard power", even where a leader has a great number of "hard power" resources at his or her disposal. Indeed, "soft power" seems to have a natural affinity with democratic leadership and governance. However, as Joseph Nye is right to emphasize, "soft power is not good per se, and it is not always better than hard power". 43 "In terms of leaders' goals, soft power can be used for good or nefarious purposes, and it can produce good or bad consequences". ${ }^{44}$ Therefore, careful analysis of a leader's performance is required even where he or she mainly draws on soft powers, and critical attention is needed "when leaders use the soft power of their charisma to weaken institutional constraints" $" 45$ designed to guarantee democratic openness and accountability.

Some problems in assessing leaders and their performance relate to the peculiarities of political systems. In Britain, the absence of a written constitution makes the identification of bad governance in terms of constitutionally suspect behavior considerably more difficult than in most other countries. The French experience suggests that there may be striking paradoxes even in countries with an established Continental tradition of constitutional government: indeed, while scholars and the public in general would appear likely to agree that violating constitutional rules represents one of the more obvious aspects of bad leadership and governance, popular notions of strong and successful presidential leadership in the Fifth French Republic have encompassed activities by the president, such as the sacking of the prime minister, that are clearly in conflict with the official rules for presidential leadership as set out in the constitution. ${ }^{46}$

Even in countries with a set of clear-cut constitutional rules and a public mind not driven by any special partiality to presidential grandesse, judging leaders involves a good deal of subjectivity which cannot be avoided even by the strictest possible application of carefully predefined criteria. Thus, while the observations and assessments presented in the next section have been guided by the criteria developed above, and with special attention to the pitfalls just high-

43 Nye, J.S.: Power and Leadership, op. cit, 318.

44 Nye, J.S.: The Powers to Lead, op. cit., 141.

45 Ibid., 143.

46 Gaffney, J.: Presidents Behaving Badly: Poor Leadership and Bad Governance in France, in: Helms, L. (ed.): Poor Leadership and Bad Governance: Reassessing Presidents and Prime Ministers in North America, Europe and Japan, Cheltenham, 2012, 87-109. 
lighted, they cannot claim to be much more than an invitation to explore this fascinating field in more detail. ${ }^{47}$

\section{IV.}

If the focus is on individual presidents and prime ministers rather than on more abstract patterns of leadership and governance, the ranking lists of political chief executives that are becoming available for an increasing number of countries provide some valuable guidance. However, even if read upside down, these ranking lists are of limited use, as they are not normally based on clear-cut criteria, and in particular do not make any distinctions between what has here been conceptualized as "poor leadership" and "bad governance".

This leaves much to be sorted out, as the case of German chancellors illustrates: Ludwig Erhard and Kurt-Georg Kiesinger are widely considered to have been the weakest holders of the German post-war chancellorship, or in the terminology of this inquiry, the two most obvious examples of poor leadership. This rather unspecific assessment though, is in need of at least some specification. To begin with, neither Erhard nor Kiesinger even tried to become an Adenauer Mark II, and at least initially their decidedly more consensus-seeking style found much favor among senior ministers and the German public. Moreover, in particular the Kiesinger government had a rather impressive performance in terms of the number of wide-ranging reform policies. Also, neither Erhard nor $\mathrm{Ki}$ esinger could be accused by any serious observer of having violated the central norms of the German constitution (though the prominence of informal coalition bodies under Kiesinger was followed with suspicion by many observers of the time). If special emphasis is being laid on the normative concept of collective cabinet government, Konrad Adenauer - generally considered as the Federal Republic's most successful chancellor - would appear to be a much more obvious candidate for the category of bad governance. By today's standards, Adenauer's performance as a leader included elements that bordered on "democratic autocracy". Adenauer also had more problems than any of his successors in accepting the independent power of other legitimate "counter-governments", in particular the Federal Constitutional Court. However, Adenauer is not the only

47 The observations presented in section IV are drawn mostly from an international joint venture on researching poor leadership and bad governance by presidents and prime ministers in the G-8, that is, in the United States, Canada, Britain, France, Germany, Italy, Russia and Japan. See Helms, L. (ed.): Poor Leadership and Bad Governance, op. cit.. 
holder of the German post-war chancellorship who has been accused of bad governance. Helmut Kohl's system of "personalized party government" with informal coalition bodies forming the political centre of the decision-making machinery within the executive branch was criticized by many observers, including committed supporters of the CDU. Assessments became even more critical as it appeared, in retrospective, that "personalized governance" and advanced informalization had to some extent paved the way for Kohl's delicate role in the CDU party funding scandal. Gerhard Schröder reduced informal coalition governance but developed unprecEdentedly close relationships with some private sector actors, which drew much criticism in particular from public lawyers. Schröder's attempts at "going public", in an attempt to put pressure on his own party within and outside the Bundestag in order to push through his highly contested Agenda 2010, was considered by many as another element of "bad governance" as it seemed to violate the established norms of parliamentary government. $^{48}$

What these observations suggest, and what is being supported by the findings of case studies on other established liberal democracies, is that the two phenomena of poor leadership and bad governance do not necessarily coincide: Weak leadership by a chief executive does not necessarily produce bad governance in terms of the public policy record of his or her government if, and to the extent that, other senior players within the administration effectively compensate for this "leadership gap". All things being equal, this would appear to be more likely in parliamentary democracies than in presidential democracies, and more likely in power-distributing consensus democracies than in power-concentrating majoritarian democracies.

There is also no essential correlation between poor leadership and bad governance in terms of a lack of respect for the core values of democratic governance and constitutional democracy. Leaders may be weak and inefficient but still be driven by the best intentions and sincere respect for the institutions and processes of democracy. To some extent, the latter would even appear to be responsible for the former. A lack of interest in, and feeling for, the operative dimensions of politics can undermine the realization of a leader's ideas and agendas in the harshly realistic world of politics. The tenures of German Chancellor Ludwig

48 For a full-length analysis see Helms, L.: Revisiting the German Chancellorship: Leadership Weakness and Democratic Autocracy in the Federal Republic, in: Helms, L. (ed.): Poor Leadership and Bad Governance, op. cit., 110-129. 
Erhard and American President Jimmy Carter provide two prominent cases in point.

However, while poor leadership and bad governance do not have to go hand in hand with each other, they often do, in particular if bad governance is understood in terms of bad policies. For example, Anthony Eden's performance as British prime minister was both poor in terms of leadership and bad in terms of governance, as was George W. Bush's as American president, or that of Yukio Hatoyama as prime minister of Japan. And their shadows may be lingering on, as all leaders tend to produce certain legacies or inheritances that may give even better leaders a difficult start. ${ }^{49}$

Of the many intriguing aspects surrounding the topic of poor leadership and bad governance, the difference that a candidate's previous political experience makes can claim to be of special interest, not only becaus it carries important implications for future reforms of candidate selection processes. In light of the available empirical findings however, there seems to be no clear-cut relationship between the length and breadth of a candidate's previous political experience and his or her performance in the office of president or prime minister. It is in particular not at all clear that more experience significantly reduces the danger of poor leadership and bad governance. Interestingly enough, and perhaps paradoxically, some cases suggest that there may indeed be a close relationship between the extended experience of candidates within the executive branch and a disappointing performance as chief executive. Among British prime ministers, Anthony Eden and Gordon Brown stand out as underperformers, even though - or perhaps precisely because - they were the long-standing heirs apparent of their respective predecessors (Winston Churchill and Tony Blair). A comparable case is that of Ludwig Erhard who succeeded Konrad Adenauer in the chancellery after having served as minister of economics and vice chancellor for 14 years. Similar examples can be found in other countries as well. A particularly blatant case in point is William McMahon, who became Australian prime minister in 1971 after serving more than 20 years as a cabinet minister, and who is widely considered to be Australia's worst prime minister ever.

49 For one of the few systematic attempts at dealing with the slippery topic of legacies and inheritances in political leadership see Rockman, B.A.: The Legacy of the George W. Bush Presidency - A Revolutionary Presidency, in: Campbell, C./Rockman, B.A./Rudalevige, A. (eds): The George W. Bush Legacy, Washington, DC, 2008, 325-348. 
The distinctive constitutional features of the presidential system make meaningful comparisons between the US and the major parliamentary democracies at this level exceptionally difficult. There is no established career path leading from a seat in the cabinet to the presidential office, whereas some cabinet experience is widely considered to be an appropriate key political qualification for the premiership in most parliamentary democracies. Also, while some post-1945 presidents spent many years in Congress before advancing to the presidency, extended experience in legislative office is by no means considered a necessary component of a presidential candidate's political qualifications, as is however true for most parliamentary democracies. The vice presidency has been described as coming closest to offering some form of apprenticeship for the office of president. $^{50}$

This having been said, some cases would appear to support the assumption that extended "apprenticeships" of presidential candidates may not always be a blessing: of the five post-war presidents with previous experience as vice president (Harry Truman, Richard Nixon, Lyndon B. Johnson, Gerald Ford, and George H.W. Bush $)^{51}$ only two, Truman and Johnson, are generally ranked among the best third of all American presidents (and if one excludes Truman, who held the vice presidency for less than three months, the average score for former vice presidents is even lower). As the son of the forty-first president, George W. Bush had a special legacy to deal with. While some observers have considered this a challenge that Bush the younger mastered impressively, most scholars and the public tend to judge the George W. Bush presidency as a spectacular failure one of the poorest American presidents ever, and arguably the worst one of the post-war period.

Bush's case is also interesting because it defies the popular assumption that poor leadership and bad governance tend to be closely related with short tenures. Even after the re-election of Barack Obama in November 2012, Bush was one of only five out of 12 post-war presidents elected for two full terms (although Harry Truman served nearly two full terms having been elevated to the presidency following the death of Franklin D. Roosevelt). Truman, Eisenhower, Reagan, Clinton and, as of late 2012, Obama are regularly ranked among the better half

50 Adkison, D.M.: The Vice Presidency as Apprenticeship, in: Presidential Studies Quarterly, 13/2 (1983), 212-218.

51 Nixon's vice-presidency, ending eight years before his winning the presidency in 1969, was obviously not a major legacy to be dealt with. 
of all post-war presidents. The correlation between performance and the length of tenure of an incumbent is even stronger in parliamentary democracies because they do not have fixed tenures of their chief executives, and are prone to experience the abrupt ending of seemingly stable governments. Many of the weakest prime ministers spent only a short time in office; many of them also moved into office between two elections rather than in the immediate aftermath of their respective party's election victory. However, there are no hard and fast rules. The powerful gatekeeper function of the parties in parliamentary democracies has allowed even tepid candidates, and prime ministers who failed to impress the public, to win and keep high executive office for an extended period of time. Indeed, in many Western European coalition democracies, the ability of the voters to change the party composition of the government, and to 'turn the rascals out', tends to be remarkably constrained. ${ }^{52}$

There are other aspects to this topic, such as the fascinating question if and to what extent "learning from negative experience" at the level of political leaders and/or citizens is possible, that it would deserve more attention in its own right but which is beyond the scope of this article. ${ }^{53}$ One other statement is necessary, however, without which the study of poor leadership and bad governance may look like an irresponsible attack on the very cause of democratic governance and democratic leaders: Many surveys place recent and incumbent leaders at the bottom of historical ranking lists, which suggests that great leaders are basically a thing of the past, but such assessments may be very much the result of the often observed phenomenon that we tend to judge leaders more generously from a greater distance. ${ }^{54}$ Other scholars documenting the erosion of political support in the advanced democracies have pointed out that "expectations have risen faster than performance". ${ }^{55}$ While this no doubt marks a disturbing development, the positive element of this observation - the trend towards a better performance on the part of politicians - should not go unnoticed.

52 Mattila, M./Raunio, T.: Does Winning Pay? Electoral Success and Government Formation in 15 West European Countries, in: European Journal of Political Research, 43/2 (2004), 263-285; Ieraci, G.: Government Alternation and Patterns of Competition in Europe: Comparative Data in Search of Explanations, in: West European Politics, 35/3 (2012), 530-550.

53 See, however, Helms, L.: Conclusion, in: Helms, L. (ed.): Poor Leadership and Bad Governance, op. cit., 195-201, here 199-201.

54 Blondel, J.: Political Leadership: Towards a General Analysis, London, 1987, 10.

55 Dalton, R.J.: Democratic Challenges, Democratic Choices: The Erosion of Political Support in Advanced Industrial Democracies, Oxford, 2004, 199. 
Poor leadership and bad governance remain prominent elements of democratic politics in the advanced industrial democracies, but it is unlikely that we are witnessing a historical decay in democratic leadership. Indeed, any fair and balanced assessment will have to take into account that the chances for presidents and prime ministers to be judged as good, or even great, have clearly deteriorated. In the age of "personalized politics" $"$ or, as some authors have put it, "presidentialized politics" $" 57$, political chief executives have not only become more visible and more powerful but at the same time more vulnerable. ${ }^{58}$ Alongside the ever-growing complexity of public and political agendas, the significant acceleration of politics marks another structural characteristic of governing in the media age that has made effective and responsible leadership more difficult. ${ }^{59}$ These developments have been accompanied by new normative agendas which measure the performance of political leaders against a set of sophisticated moral standards. ${ }^{60}$ Thus, while skepticism and critical attention are advisable, cynicism would be utterly misplaced and dangerous. It might fuel populist critiques of democratic leadership and undermine the public's respect for, and trust in, even the most capable and committed democratic leaders.

56 McAllister, I.: The Personalization of Politics, in: Dalton, R.J./Klingemann, H.-D. (eds): The Oxford Handbook of Political Behavior, Oxford, 2007, 571-588; Karvonen, L.: The Personalisation of Politics: A Study of Parliamentary Democracies, Essex, 2010; Campus, D.: Mediatization and Personalization of Politics in Italy and France: The Cases of Berlusconi and Sarkozy, in: The International Journal of Press/Politics, 15/2 (2010), 219-235; Garzia, D.: The Personalization of Politics in Western Democracies: Causes and Consequences on Leader-Follower Relationships, in: The Leadership Quarterly, 22/4 (2011), 697-709; Langer, A.I.: The Personalisation of Politics in the UK: Mediated Leadership from Attlee to Cameron, Manchester, 2012; Kriesi, H.-P.: The Personalisation of National Election Campaigns, in: Party Politics, 18/6 (2012), 825-844.

57 Poguntke, T./Webb, P. (eds): The Presidentialization of Politics: A Comparative Study of Modern Democracies, Oxford, 2005.

58 Helms, L.: Democratic Political Leadership in the New Media Age: A Farewell to Excellence?, in: The British Journal of Politics and International Relations, 14/4 (2012), 651-670, here 660.

59 Rosa, H.: The Speed of Global Flows and the Pace of Democratic Politics, in: New Political Science, 27/4, 445-459; Hassan, R.: Empires of Speed: Time and the Acceleration of Politics and Society, Leiden, 2009.

60 Kennedy, M./Hoxie, R.G./Repland, B. (eds): The Moral Authority of Government: Essays to Commemorate the Centennial of the National Institute of Social Sciences, New Brunswick/London, 2000; SaintMartin, D./Thompson, F. (eds): Public Ethics and Governance: Standards and Practices in Comparative Perspective, Oxford, 2006. 